\title{
The Effect of Learning Strategy and Self Confidence Toward Student's Learning Outcomes in Elementary School
}

\author{
${ }^{*}$ Leorisma Sihotang ${ }^{1}$; Deny Setiawan ${ }^{2}$; Daulat Saragi ${ }^{3}$ \\ ${ }^{1}$ (Post Graduate, State University of Medan, Medan, Indonesia) \\ ${ }^{2}$ (Lecturer, State University of Medan, Medan, Indonesia) \\ ${ }^{3}$ (Lecturer, State University of Medan, Medan, Indonesia), \\ Corresponding Author: Leorisma Sihotang
}

\begin{abstract}
This study aimed to analyze (1) Student's learning outcomes that are learned by Group Investigation (GI) learning strategy is higher than learning result student civic education which is taught by Student Team Achievement Division (STAD) learning strategy (2) Students who have self confidence (3) The interaction of learning strategies and self confidence in influencing student's learning outcomes Student civic education is higher than students with low self confidence. The population of this study is the students of class $V$ Elementary School 067240 Medan Tembung consists of 2 classes with the number of students 60 people. The sample of this research is determined class sample that is class $V-1=30$ people to follow the learning by using Group Investigation study strategy and class $V-2=30$ people to follow learning by using STAD learning strategy. The sampling technique is done by total sampling. Research instruments to measure learning outcomes were used multiple-choice test forms with and questionnaires for students' self-confidence. The data analysis technique used two-way ANOVA at significance level $\alpha=0,05$. The research findings show: (1) There are differences in learning outcomes student civic education using Group Investigation strategy with STAD strategy. The learning outcomes student civic education using Group Investigation learning strategy with an average value of 89.23, while the learning outcomes student of civic education using STAD learning strategies obtained an average score of 83.67, (2) There is a difference in learning outcomes Student civic education has a belief High self-esteem with low self confidence. Students who have high confidence with the average value of civic education learning outcomes of 89.55, while students who have low confidence to get the average value is 83.55 , (3) There is interaction learning strategies and confidence in affecting learning outcomes student civic education.
\end{abstract}

Keywords : Learning Strategies, Self Confidence, and Learning Outcomes

Date of Submission: 07-07-2017

Date of acceptance: 17-07-2017

\section{Introduction}

Civic education lesson are very important and essential lesson for students to learn and master. Hence the civic education lesson can not be separated from everyday life. Civic education lesson is also one lesson that has characteristics different from other lessons such as math lessons. Students' must have good understanding, mastery of civic education. In addition, civic education lessons are also used to form student personality so that students' become Indonesian citizens who are intelligent, skilled, and characterized by Pancasila and the 1945 Constitution. The civic education course is one of the subjects in education level starting from Elementary school up to college. This is because this subject is a subject that brings the mission of making Indonesian citizens a good citizen. Subjects civic education is a subject that focuses on the formation of citizens who understand and are able to exercise their rights and obligations.

But the learning of civic education is still very far from expected. The strategy used always use the old habits of student teams achievement division strategy that is by conveying the learning strategy orally or discussed without discussing more in-depth material learned and also less attention to the characteristics of students who should be considered in the learning. Teachers tend to be text oriented and have not emphasized the students' thinking processes independently. The discussions discussed sometimes do not fit the context and issues that are developing in society especially those related to civic education.

Implementation of learning is expected to give effect to the improvement of student learning outcomes. Learning outcomes as a product of the teaching and learning process are not the result of a single process, but are part of the interaction of a number of learning success factors that can be sourced from within students (internal factors) or outside the student's self (external factors). Various efforts have been made by the government to innovate in education. Innovation is usually done with attention to three important reasons, namely efficient, effective and comfortable. Efficient means that the time available for teachers should be 
utilized as well as possible. Effective means the lessons should produce results that are beneficial to the students' or the community, while convenience means learning resources, media learning aids, methods prescribed in such a way as to provide a passion for teaching and learning for students and teachers. In an effort to improve the quality of education, especially in improving educational outcomes, one of which must be developed is the process of teaching and learning which is the most fundamental activities in the implementation of education. Thus successful or not achievement of educational goals influenced by various factors such as the successful implementation of teaching and learning process conducted by teachers in the classroom.

Successful implementation of learning is also related to the learning strategy used. Learning strategy is one component that is important and very profitable in the success of the educational process. A number of instructional strategies have been applied in schools to achieve success in the educational process, however, given the variations in goals to be achieved, different learning environments, different student circumstances, different material characteristics, etc., Can be devised a good strategy for all types of teaching and learning activities. Teaching process conducted by teachers should have a strategy so that students are able to follow the learning activities so as to obtain good learning outcomes.

One of the steps to apply the learning strategy is to master the techniques of material presentation, or so-called learning strategy. In fact many learning strategies can be used in learning, but not every learning strategy can be applied in any material, so the selection of learning strategies is very important in order to achieve the learning objectives. So before the implementation of teaching and learning activities required a mature thought in the selection of appropriate learning strategies for a basic competence to be presented. One of the learning strategies that can be done is group investigation learning strategy. The group investigation learning strategy is a teaching strategy that teaches in such a way that the students not only learn the material, but the students are also taught special skills in order to work with the group. The success of one person is a joint success. With the learning method is expected to involve students actively in the learning process so that students are encouraged to understand the material taught by the teacher so it is expected to be more interesting and interactive so it can be used as one solution to improve the quality of learning.

[1] suggests that in group investigation strategy there are three main concepts, namely research or inquiri, knowledge or knowledge, and the dynamic of the learning group. According to [2] in this study the teacher should direct, help the students find information, and act as one learning resource, capable of creating a social environment characterized by democratic environment and scientific process.

In addition to learning strategies, things that need to be considered in the learning process is the characteristics of students. One of the characteristics of students who can affect the improvement of learning outcomes is confidence. According to [3] self-confidence is an adequate self-ability and aware of the capabilities it possesses and can utilize appropriately. Based on the results of the study [4] that self-confidence is a belief that a person possesses that he is capable of behaving as needed to obtain the desired results. Selfconfidence is self-sufficient, selfless, tolerant, ambitious, optimistic, not shy, convinced by his own opinion and not excessive. Successfully achieving a learning outcome allows him to learn more smoothly in reaching the next stage. In general, student achievement in Indonesia is determined by its cognitive ability in understanding the distribution of subject matter that has been determined in the curriculum. [5] states that cognitive behavior is an act of knowing or thinking about situations in which behavior occurs. Behavior depends on the insight (observation or understanding) of the relationships that exist in the situation. [6] assert that in cognition occurs the process of thinking and observing processes that produce, acquire, store, and produce knowledge.

Based on a preliminary study at the research site, the teaching-learning process of the students is highly focused on the oral narrative of a given material (teacher-centered). Students are less motivated to study hard because of the lack of opportunity given to them. In the learning activity of education civic there is a limit of achievement of the minimum learning achievement that must be achieved by the students is called Minimal Exhaustiveness Criteria. Based on the National Education Standards civic education completeness of at least 70. The low value obtained by students with data on the value of education Elementary School 067240 Medan Tembung still not optimal, thus the use of ordinary learning process done to give less satisfactory results. In accordance with the description of the above phenomenon, it is understood that to improve the learning outcomes of civic education students need to use learning strategies that are able to assist students in discovering the concepts and principles in the material learned. The strategies used are Group Investigation (GI) learning strategies and Student Teams Achievement Division (STAD) learning strategies with respect to self-confidence as a factor influencing the improvement of student learning outcomes. For that reason, it is necessary to do research on group investigation learning strategy and student teams achievement division strategy related with students' self confidence to improve student learning outcomes in civic education subjects. 


\subsection{Learning Outcomes}

According to [7] learning is as a change of behavior, experience and practice. So learn to bring about a change in the individual learning. The change is not only about a number of experiences, knowledge, but also forming skills, habits, attitudes, understandings, interests, adjustments. In this case it covers all aspects of the organization or individual of the learning individual.

[8] suggests that learning is a process of changing behavior through education or more specifically through training procedures. The change itself gradually begins with something that it does not recognize, to then be mastered or possessed and used until it is evaluated once by the learning process.

[9] suggests that learning is trying (practice) in order to gain an intelligence (knowledge). In this case cleverness can be demonstrated with satisfactory achievement of the business he achieved himself. Another suggestion is that learning is the process by which a person undertakes to gain a whole new behavioral change as a result of his own experience in interaction with the environment.

According to [11] learning is a process that can bring about changes in one's knowledge, actions, and behavior. Meanwhile, according to [12] learning is defined a process of development, knowledge, skills, and attitudes that occur when a person interacts intensively.

Based on some opinions expressed above then the authors conclude that the conclusion that learning is a process in the individual. So the individual changes his behavior as a result of the learning experience. The learning process is essentially to develop the activities and creativity of learners, through various interactions and learning experiences. But in practice we often as a teacher is not aware, that there are many learning activities that we implement it inhibits the activity and creativity of learners. In the learning process must first determine the goals to be achieved and formulate what ability should be owned by students after following the learning activities. Understanding the learning objectives proposed by [13] explains that the purpose of learning is the statement statement about the behavioral skills that are expected or owned by students after the students receive the teaching process. While [14] the learning objectives are the abilities that must be possessed by the students after they learn a particular subject in a single meeting.

Learning objectives are the skills (competencies) or skills that students hope to have after they have learned a particular subject in each learning session. Because only teachers who know the characteristics of learning materials that are learned, then the task is to formulate the learning objectives are teachers. The components that are considered in the formulation of the indicators of learning objectives are who is expected to achieve the objectives or learning outcomes, what behavior is expected to be achieved, under what conditions the conditions of learning are displayed.

According to [11] that learning outcomes can be grouped into five categories, namely intellectual skills, cognitive strategies, verbal information, motor skills and attitudes. [1] suggests that learning outcomes are also behavioral or behavioral changes. This behavior can certainly be understood in the form of behavioral knowledge, skills, and mastery of values (attitude). These knowledge, skills and attitudes are of course related to the learning outcomes in the cognitive domain consists of six categories: knowledge, understanding, application, analysis, synthesis and evaluation. While affective domain with attitude that consists of five aspects, namely acceptance, answers or reactions, assessment, organization and internalization. And the last psychomotor domain concerns the results in this paper refers to the cognitive domain.

Along with the development and science came the science called the science of civic education. [15] argued that the science of civic education as a study of the behavior of people and society in choosing how to use scarce resources and have some alternative use, in order to produce various commodities, to then channel both current and future doings to various individuals and Groups within a community.

Based on some of the opinions expressed above it can be authors point out the conclusion that the learning outcomes civic education is the ability of students in describing the behavior associated with daily life in the student environment. Viewed from the teacher of learning materials that should be learned or delivered in learning activities. Viewed from the students of the teaching materials it must be studied students in order to achieve the standard of competence and basic competence to be assessed by using assessment instruments are prepared based on learning achievement indicators.

\subsection{Learning Strategy}

Learning strategy is a learning activity that must be done teachers and students for the purpose of learning can be achieved effectively and efficiently. From that opinion, Dick and Carey cited by [15] mentioned that the learning strategy is a set of materials and learning procedures that are used together to generate student learning outcomes.

According to [16] that there are four basic strategies in teaching and learning are:

1) Identify and define the specifications and qualifications for changes in the students' behavior and personality as expected

2) Choosing a teaching and learning approach based on community aspirations and worldviews 
3) Selecting and establishing the most appropriate and effective teaching procedures, methods and techniques that can be used by teachers in carrying out their teaching activities

4) Establish norms and minimum limits of success or criteria and standards of success can be used as guidance by teachers in evaluating the results of teaching and learning activities which will then be used as feedback for improvement of the relevant instructional system as a whole.

The Group Investigation (GI) cooperative learning strategy developed by [17] mentions that in group investigations students are given responsibility for their work, either individually, in pairs or in groups. Each investigative group consists of 3-5 people, and finally students can combine, present and summarize their answers. Group Investigation is one form of cooperative learning strategy that emphasizes the participation and activities of students to find their own lesson (information) lessons to be learned through the materials available, for example from textbooks or students can search through the internet. Students are involved since the planning, both in determining the topic and how to study it through investigation. This type requires students to have good communication skills as well as in group process skills. Group Investigation strategies can train students to foster independent thinking skills. Active student involvement can be seen from the first stage to the final stage of learning.

[18] argued that STAD Cooperative Learning (Student Team Achievement Division) is one of the cooperative learning that is applied to face the heterogeneous student's ability. Where this strategy is seen as the most simple and direct strategy of cooperative learning approach. This strategy was first discovered and developed by educational researchers at John Hopkins University of the United States by providing a form of cooperative learning. In it students are given the opportunity to collaborate and elaborate with peers in the form of group discussions to solve a problem.

[19] the core of the STAD is that the teacher conveys a material, then the students join in a group of four or five people to solve the problems the teacher gives. After completion they submit their work singly to each group to the teacher. The students are then given individual tests / quizzes by the teacher. The score of the quiz or test results in addition to being used to determine the individual score is also used to determine the score of the group.

Based on the opinions expressed above, the authors can put forward the conclusion that STAD learning is a learning that is applied to face the heterogeneous student's ability. Where this strategy is seen as the most simple and direct strategy of cooperative learning approach. In it students are given the opportunity to collaborate and elaborate with peers in the form of discussion. STAD type cooperative learning (Student Team Achievment Division) is one type of cooperative learning that involves small groups during teaching and learning activities to work with a team, complete a task or to achieve common goals.

\subsection{Self Confidence}

Beliefs are the attitudes that must be owned by those who want to succeed because without selfconfidence it is impossible for a person to confront the problems he faces. Belief in him is also a picture of ability and truth in drawing conclusions about what is best to succeed in accordance with what he expects, when it has its own shortcomings.

[20] says that Self Confidence is a willingness to stand alone, to feel free and to be aware of his strength, as well as to face everything in his life. Furthermore, [21] says self-esteem is the conviction as needed to result in expected results. His promise [22] suggests that confidently means that as a person who can work actively and responsibly and plan for the future. So people with high self confidence are usually free to direct their choices with their energy and involve a variety of alternative thinking that is, actively approaching goals, can distinguish between knowledge and feelings and give decisions influenced by their intellectual abilities independently analyzing and controlling his mind in the right relationship, responsible for his decision, courageous and able to correct his mistakes.

According to [23] said that people who have confidence, will dare to try new things in new situations, because they feel quite safe, calm, and have their own measure of failure and success.

Self-confidence that grows in a person not just but the development of that belief begins from the family environment which is the main and first tool for a person to receive education from both parents who will give color for his personality later.

According to [24] that self-confidence is not inherited or innate nature but is derived from life experience and can be educated and added by educators with various efforts to shape and improve selfconfidence. Meanwhile [25] explains that the process of formation of confidence through several stages:

1) The establishment of a good personality in accordance with the development process that gave birth to certain advantages

2) A person's understanding of the advantages they have and give birth to strong beliefs to be able to do everything by utilizing the advantages 
3) Understanding and positive reaction of a person to the weaknesses that have in order not to cause low selfesteem and difficulty adjusting

4) Experience in living various aspects of life by using all the advantages that exist in him.

It is affirmed by [26] that the best thing to do for self-belief is by doing prevention and coaching as early as possible, especially in terms of expressing the feeling of self as a capital towards the development of self-confidence. Thus, the individual will practice it in everyday life, dare to express his wishes and opinions either to teachers, friends, or parents. With the formation of confidence to an individual individual causes the individual is more creative, dare to take risks and dare to experiment which in the end can produce proficiency.

The development of healthy confidence is established as the ability to think optimally, achievement, active and aggressive in approaching problem solving, and can not be separated from the environmental situation that supports it. According to [27] people who lack self-confidence tend to be pessimistic, apathetic, withdraw from intercourse and dare not take any decision on their own.

\subsection{Population and sample}

\section{Method}

The research was conducted on the students of grade V of elementary school 067240 Medan Tembung, Year 2016/2017, consisting of two classes V-1, V-2 with 60 students. Each class consists of V-1 class of 30 people and V-2 class of 30 people. The sample is a portion of the population that is considered to represent the population to serve as a source of information or data sources in a study. The sampling technique is done by total sampling technique that is from two existing classes overall set as sample. Thus the sample is defined as class V-1 and class V-2 totaling 60 people

\subsection{Data collection techniques}

This type of research is a quasi experimental research is research that aims to determine the effect of something imposed on the subject of the student. The study involved two different sample classes treated. The experimental class is treated in the form of learning using Group Investigation strategy. Control class is treated in the form of STAD learning strategy. The variables of this study consist of three types of independent variables, moderator variables and dependent variables. This research will use experimental method with $2 \times 2$ factor design. Through this design will be compared the influence of learning strategies of GI and STAD types in terms of self-confidence as a moderator variable and the acquisition of learning outcomes civic education as a dependent variable. The study involved two different treatment classes. To know the result of student learning done by giving test in both class before and after given treatment. The experimental design of quasi experiments was design: two group pretest -posttest design. These variables will be included in the research design.

Table 1. Research design

\begin{tabular}{|l|l|l|}
\hline \multicolumn{1}{|c|}{ SP $(\mathrm{A})$} & $\left(\mathrm{A}_{1}\right)$ & $\left(\mathrm{A}_{2}\right)$ \\
$\mathrm{KP}(\mathrm{B})$ & $\mathrm{GI}$ & STAD \\
\hline $\mathrm{B}_{1}(\mathrm{KT})$ & $\mathrm{A}_{1} \mathrm{~B}_{1}$ & $\mathrm{~A}_{2} \mathrm{~B}_{1}$ \\
\hline $\mathrm{B}_{2}(\mathrm{KR})$ & $\mathrm{A}_{1} \mathrm{~B}_{2}$ & $\mathrm{~A}_{2} \mathrm{~B}_{2}$ \\
\hline
\end{tabular}

Data collection techniques used in the research are questionnaires and test techniques. The questionnaire technique used to determine students' confidence level in learning, as well as test techniques used to determine the success of students after attending a series of learning activities. Before the test is used, first reviewed the validity of its content through the opinions of experts as a validator. Content validity refers to an instrument that has the conformity of the content in the reveal / measure to be measured [28]. In addition, content validation is also intended for the content of the test tested in accordance with the contents of the current curriculum. Validation of this content is determined by expert judgment, to give an idea of the validity of the test before it is followed up. Test results learning civic education in the form of 30 items, Each correct answer is given the value of one and wrong answers are given a zero. Confidence test in the form of self confidence measurement instruments used in this study in the form of a questionnaire. This instrument aims to measure students' confidence level in learning. Confidence is a confidence process that is a sense of confidence in the question by using the process of feeling that students have in solving real-world and abstract situations using Likert-scale measures. The questionnaire items consist of four choices of answers: strongly agree (SA), agree (A), disagree (D), strongly disagree (SD). Both of these instruments are validated by the lecturers of Graduate State University of Medan, as panel of experts in determining the suitability of the test indicators. After the process of revision and improvement of suggestions provided by the expert, it is concluded that the test has been able to be used to determine student learning outcomes and student confidence.

Data collection is done in two stages, the first step is collecting data about students' confidence level and second stage collecting data about student learning outcomes. Data obtained in the study were analyzed 
descriptively and inferentially. Inferential statistical analysis, to test the hypothesis. Before testing the hypothesis is tested requirement that is normality test of research data with technique of Liliefors, then continued with homogeneity test by using Bartlett test. To test the hypothesis of this study used ANOVA $2 \times 2$ (two path ANOVA) with F test with significant level $\alpha=0,05$.

\section{Results}

Based on the results of processing and analysis tehadap research data can be presented in Table 4 . below.

Table 4. Anova Test Results 2 x 2.

\begin{tabular}{|c|c|c|c|c|c|}
\hline Source & \begin{tabular}{|l} 
Type III Sum of \\
Squares
\end{tabular} & Df & Mean Square & $\mathrm{F}$ & Sig. \\
\hline Corrected Model & $1240.453^{\mathrm{a}}$ & 3 & 413.484 & 9.093 & .000 \\
\hline Intercept & 446773.226 & 1 & 446773.226 & $9.825 \mathrm{E} 3$ & .000 \\
\hline Learning strategies & 349.901 & 1 & 349.901 & 7.695 & .008 \\
\hline Confidence & 454.050 & 1 & 454.050 & 9.985 & .003 \\
\hline Strategi $*$ Trust & 326.745 & 1 & 326.745 & 7.186 & .010 \\
\hline Error & 2546.397 & 56 & 45.471 & & \\
\hline Total & 452203.000 & 60 & & & \\
\hline Corrected Total & 3786.850 & 59 & & & \\
\hline
\end{tabular}

a. R Squared $=, 328$ (Adjusted R Squared $=, 292)$

\subsection{Discussion}

\section{Discussion And Conclusions}

\subsubsection{Learning outcomes Student civic education using group investigation strategy is higher than STAD} strategy

The results of the analysis of research data through two-lane anova test was decided to reject Ho and accept Ha. This indicates that the learning outcomes of civic education of students who are taught using Group Investigation study strategy is higher than learning outcomes student civic education taught using STAD learning strategy.

In the success of student learning, many factors that can give effect to student learning outcomes. These factors can come from students themselves, such as self-confidence and can also come from outside the students such as the use of learning strategies used by teachers in the implementation of teaching and learning processes in the classroom. [29] suggests that the factors that influence learning outcomes are three kinds:

1. Internal factors, external factors and learning approach factors. Internal factors are factors that come from within the students for example intelligence, motivation, talent, creativity, attitude, interests, and health level.

2. External factors are factors that come from outside the student self such as school environment, home environment, family conditions, learning facilities and study time. Factors that also determine the learning approach factors. This factor is related to all the ways and strategies used by students in supporting the effectiveness and efficiency of the process of studying certain materials.

In schools, especially during the implementation of teaching and learning activities, students will follow the learning process with learning strategies that have been used by teachers in the classroom. Therefore, every teacher needs to pay attention by choosing and preparing a learning strategy that is really appropriate to the situation and condition so that really able to realize effectiveness and efficiency of learning process in class. This is in accordance with the opinion [30] suggests that in school, the teacher factor and the way of teaching are very important factors. That is, the mastery of teachers against learning strategies is needed to improve the professional skills of teachers in teaching, therefore teachers should be able to determine the most appropriate strategy and in accordance with the goals, characteristics of students and materials to be delivered.

In this case of course instructional strategy needs to be designed oleg teachers well, so effective and efficient in its use so that help towards achieving the purpose of learning. Therefore, teachers need to consider several things as a consideration for designing learning strategies, especially with consideration in choosing a learning strategy that is able to achieve learning objectives. The results of this study have shown that learning outcomes of civic education students who are taught by Group Investigation strategy is higher than the learning outcomes by using STAD learning strategies. The learning process that the Group Investigation strategy provides is a learning process that provides an opportunity for students to respond critically, analytically to the subject matter so that the values contained in the subject are really understood and believed by the students. Group Investigation learning strategy is a learning strategy that conducts a series of learning activities that students do 
without leaving a sense of boredom and burden so that learning civic education is not boring scary because Group Investigation emphasizes active involvement means students are more dominant role in learning while teachers as facilitators, classroom arrangement, teachers Should be more creative to design the classroom before learning begins such as lighting, color, table and chair arrangements, plants, all things that support the learning process, it is useful to provide the atmosphere and spirit to receive lessons.

Group Investigation learning strategy can encourage students to learn actively and passionately, and students more easily and quickly master the subject according to the taught material. In addition, by using Group Investigation learning strategy, students can carry out the task and study in stages and cooperation, making it easier to master the material taught by the teacher thus the student learning outcomes will be higher.

Group Investigation's learning strategy not only puts students in a central position in all teaching programs, more than that is expected to foster students' confidence in following the subjects of civic education. Based on this research based learning strategy where interaction occurs in accordance with the characteristics of students. The Group Investigation study strategy emphasizes enjoyable learning according to student characteristics and psychologically positively affects students in whom they prefer to learn the investigation rather than simply listening to the lecture delivered by the teacher.

Group Investigation's learning strategy aims to foster student participation in doing tasks, or cultivate questions during learning. Then the Group Investigation learning strategy is a way of teaching where the teacher gives the opportunity to the students to be active in finding their own problems related to the subject matter studied. With the emergence of problems teachers will play a role to explain the problem and develop it so as to arouse students' thinking.

Unlike the learning strategy student team achievement division has not maximized the potential of students. Where students only act as recipients of information. Class activities that do not vary too tend to be boring. Students hear the material delivered by the teacher through the lecture, then the students do the task, Question and answer and take conclusions. This strategy is very demanding ability of a teacher in communicating and lecturing. Teachers should be able to make each student focus his attention on the material it conveys. Teachers who are not good at speaking, will make delivering material like this feel very boring.

\subsubsection{Learning outcomes civic education students have higher self confidence from higher students have low self confidence}

Based on the analysis of research data using anava two lines decided to reject Ho and accept Ha. This means that students' civic learning outcomes have higher self-esteem than students having low self-esteem. From the results of data analysis found that the average learning outcomes of civic education students who have high confidence is better than students who have low self-esteem. This indicates that students who have high self-esteem on average have better learning outcomes of civic education than students with low self-esteem. Thus, students who have high self-esteem better understand the lesson of civic education than students who have low self-esteem. High confidence can improve understanding of a problem or problem. The higher the confidence of a person will be more critical understanding of a problem or problem. Thus through understanding an issue in teaching and learning activities in the classroom will improve understanding of the given material. So students who have high confidence will better understand the problems or problems of civic education in learning activities so that the results of learning is better than students who have low self-esteem. By having good learning outcomes then students can realize in this life is always changing, or do not get what is desired, arise dissatisfaction. Then students have high confidence also have a good understanding of the subject matter so that students will have confidence in mastery and skills himself.

\subsubsection{Interaction between learning strategy and self confidence against student learning outcomes}

Based on the analysis of research data through anava test it was decided to reject Ho and accept Ha. That is, there is an interaction between learning strategies and confidence in influencing student learning outcomes Student citizenship education. The result of research known that there is interaction of learning strategy and student's confidence in influencing student learning result of student's civic education. On average the group of students who have high self-esteem and are taught using Group Investigation learning strategies have better civic education learning outcomes than using the Student Team Achievement Division learning strategy. Then on average the civic education learning outcomes of the group of students who have low selfconfidence and taught by Group Investigation study strategy is lower than the group of students who have low self-esteem but are taught using the student team achievement division's learning strategy. In other words for groups of students with low self-esteem it is better to use the student team achievement division learning strategy compared to using Group Investigation learning strategies, although the difference in learning outcomes of civic education is insignificant. So in this case learning strategies and students' self-confidence is significant enough to influence the learning outcomes of student civic education. Based on educational learning outcomes student civic education as a whole, an increase in learning outcomes before treatment and after treatment, especially on the treatment of Group Investigation learning strategies. Whereas in the Student Team 
Achievement Division's learning strategy class, although there is an increase in learning outcomes, the average increase in learning outcomes is better than the average of learning outcomes that have been carried out in the study sites.

\subsection{Conclusions}

Based on the results of research and discussion it can be concluded as follows:

1. There are differences in learning outcomes Student civic education using Group Investigation strategy with STAD strategy. Learning outcomes Student civic education using Group Investigation learning strategy with an average value of 89.23, while the learning outcomes student civic education using STAD learning strategies obtained an average value of 83.67 .

2. Differences in learning outcomes Civic education students have high self-confidence with low self-esteem. Students who have high confidence with the average value of learning outcomes civic education that is equal to 89.55 , while students who have low confidence to get the average value is 83.55 .

3. There is an interaction of learning strategies and self-confidence in influencing student learning outcomes student civic education. With result of Anova AxB test known that $\mathrm{F}_{\text {counted }}=7,186$ and $\mathrm{F}_{\text {table }} 0,05(1,60)=$ 4,000. Because 7,186>4,000.

\section{References}

[1] Winaputra, H.U.S. 2001. Strategi Belajar Mengajar. Jakarta : Grasindo

[2] Depdiknas. 2005. Kurikulum Berbasis Kompetensi (KBK). Jakarta : Depdiknas

[3] Istiana. 2009. Pengaruh Metode Pemberian Tugas dan Kepercayaan Diri Terhadap Hasil Belajar Psikologis Pendidikan Fakultas Psikologi UMA. Tesis Medan : PPs UNIMED

[4] Erviningsih. 2010. Pengembangan Pemahaman Konsep dan Kemampuan Pemecahan Masalah Fisika Bagi Siswa SMA Dengan Pemberdayaan Strategi Perubahan Konseptual Berseting Investigasi Kelompk.. Tesis. UNJ.

[5] Damini, Marialuisa dkk. Enhancing Intercultural Sensitivity through Group Investigation - a Co-operative Learning Approach. Journal of Co-operative Studies, 46:2, Autumn 2013: 24-31 ISSN 0961 5784. Hal. 24-31

[6] Aziz, Abdul El Quusy. 2004. Pokok-pokok Kesehatan Jiwa Mental. Jakarta : Bulan Bintang.

[7] Nasution, N dan Suryanto. 2008. Evaluasi Pengajaran. Jakarta : PPUT

[8] Shalahuddin. 2005. Pengantar Psikologi Pendidikan. Jakarta : Renika Cipta

[9] Purwodarminta. 2003. Kamus Umum Bahasa Indonesia. Jakarta: Depdiknas.

[10] Slameto. 2005. Belajar dan Faktor-Faktor yang Mempengaruhinya, Jakarta : Rineka Cipta

[11] Gagne, R.M. 1992. The Condition of Learning and Theory of Instruction. Fourth Edition. New York : Holt. Rine Hart and Winston.

[12] Fayombo,Grace..Learning Styles, Teaching Strategies and Academic Achieveme among some Psychology Undergraduates in Barbados. Journal International Caribbean Educational Research Journal. Vol. 3, No. 2, September 2015, 46-61. Hal. 46.61

[13] Sudjana, Nana. 2005. Dasar-dasar Proses Belajar Mengajar. Bandung : Sinar Baru

[14] Frandson, N.A. 2007. How Children Leran. New York : MC. Garw Hill Book

[15] Ibrahim, Muslim.2000. Pembelajaran Kooperatif, UNESA University Press, Surabaya.

[16] Djamarah, S. 2002. Psikologi Belajar. Jakarta : Rineka Cipta

[17] Pakasi. 2001. Anak dan Perkembangan. Jakarta : Gramedia

[18] Romizowski, A.J. 2001. Design Instructional System. London.: Kogan

[19] Tim MKPBM, 2001, Strategi Pembelajaran matematika Kontemporer, UPI Bandung, Bandung

[20] Mangunsarkoro.2001. Ilmu Adab dan Kemasyarakatan. Jakarta : Harapan Masa

[21] Santyasa. 2009. Pengembangan Pemahaman Konsep dan Kemampuan Pemecahan Masalah Fisika Bagi Siswa SMA Dengan Pemberdayaan Strategi Perubahan Konseptual Berseting Investigasi Kelompok .Tesis. UPI

[22] Şimşek. Ufuk. The Effects Of Cooperative Learning Methods On Students' Academic Achievements In Social Psychology Lessons. International Journal on New Trends in Education and Their Implications July 2013 Volume: 4 Issue: 3 Article: 01 ISSN 1309-6249. Hal. 5-9.

[23] Suprijono, Agus. 2010. Cooperative Learning Teori \& Aplikasinya. Yogyakarta: Pustaka Pelajar.

[24] Lirirs. 2007. Pengaruh Keikutsertaan dalam Program Pengembangan Pribadi Terhadap Rasa Percaya Diri Siswa Sekolah Pengembangan Pribadi. Tesis. UPI

[25] Hakim. 2002. Mengatasi Rasa Percaya Diri. Jakarta : Puspa Swara

[26] Istiana. 2009. Pengaruh Metode Pemberian Tugas dan Kepercayaan Diri Terhadap Hasil Belajar Psikologis Pendidikan Fakultas Psikologi UMA. Tesis Medan : PPs UNIMED

[27] Gunarsa. 2006. Psikologi Praktis Anak, Remaja dan Keluarga. Jakarta : Gunung Mulia

[28] Margono. 2009. Metodologi Peneltian Pendidikan. Jakarta: PT Rineka Cipta

[29] Sangadji, Sopiah. Implementation of cooperative learning with group investigation model to improve learning Achievement of vocational school students in Indonesia. International Journal of Learning \& Development. ISSN 2164-4063. 2016, Vol. 6, No. 1. Hal. 1-13.

[30] Syamond, S.2009. Teach Your Self Personal Effiency. London : The English Universitas Press

\footnotetext{
Leorisma Sihotang. "The Effect Of Learning Strategy And Self Confidence On Student's Learning Outcomes Of Civic Education In Primary School." IOSR Journal of Research \& Method in Education (IOSR-JRME) 65.72 (2017): 65-72.
} 